\title{
ESTABLISHMENT OF AN EFFICIENT PLANT REGENERATION CULTURE PROTOCOL AND ACHIEVEMENT OF SUCCESSFUL GENETIC TRANSFORMATION IN JATROPHA CURCAS L.
}

\author{
Ying Liu, ${ }^{*}$ Guoxuan Liu, ${ }^{1}$ Yali Yang, ${ }^{2}$ Sufang Niu, ${ }^{3}$ Fuguang Yang, ${ }^{4}$ \\ SHAOXIA YANG, ${ }^{1}$ JiANIAN TANG $^{1}$ and JiANPING Chen $^{5}$ \\ ${ }^{1}$ Department of Biotechnology, Faculty of Agricultural Science, Guang Dong Ocean University, \\ Zhanjiang, Guangdong, P.R. China \\ ${ }^{2}$ Department of Basic Medicine, School of Medicine, Jiaying University, Meizhou, Guangdong, \\ P.R. China \\ ${ }^{3}$ Department of Marine Biology, Fisheries College, Guang Dong Ocean University, Zhanjiang, \\ Guangdong, P.R. China \\ ${ }^{4}$ Faculty of Mathematics and Computer Science, College of Software Engineering, \\ Guang Dong Ocean University, Zhanjiang, Guangdong, P.R. China \\ ${ }^{5}$ Department of Food Science and Engineering, College of Food Science and Technology, \\ Guang Dong Ocean University, Zhanjiang, Guangdong, P.R. China
}

(Received: July 18, 2017; accepted: October 3, 2017)

\begin{abstract}
An efficient and reproducible protocol is described for shoot-bud regeneration and Agrobacterium tumefaciens-mediated genetic transformation of $J$. curcas. Treating the explants with high concentrations $(5-120 \mathrm{mg} / \mathrm{L})$ of TDZ for short durations $(5-80 \mathrm{~min})$ before inoculation culture increased significantly the regeneration frequency and improved the quality of the regenerated buds. The highest shoot-buds induction rate $(87.35 \%)$ was achieved when petiole explants were treated with $20 \mathrm{mg} / \mathrm{L} \mathrm{TDZ}$ solution for $20 \mathrm{~min}$ and inoculated on hormone-free MS medium for 30 days. Regenerated shoots of $0.5 \mathrm{~cm}$ or a little longer were isolated and grafted to seedling stocks of the same species, and then the grafted plantlets were planted on half-strength MS medium containing $0.1 \mathrm{mg} / \mathrm{L} \mathrm{IBA}$ and $2 \mathrm{mg} / \mathrm{L}$ sodium nitroprusside (SNP). This grafting strategy was found to be very effective, to obtain that healthy grafted plantlets ready for acclimatization within 20 days. By the above mentioned protocol and with general Agrobacterium mediated genetic transformation methods only 65 days were needed to obtain intact transgenic plants.
\end{abstract}

Keywords: Jatropha curcas - Petiole explants - Plant regeneration - Genetic transformation

\section{INTRODUCTION}

Jatropha curcas L. is a type of woody plant widely distributed in the tropical and sub-tropical areas and belonging to the Euphorbiaceae family [2]. This tree is most famous for the high oil content in its seeds (up to $60 \%$ ), which could be easily processed to replace the conventional fossil diesel [9]. There has been a surge of interest in $J$. curcas cultivation around the world since studies showed that its methyl ester could yield biodiesel $[1,13]$.

\footnotetext{
*Corresponding author; e-mail address: 513109772@qq.com; liuying85168@126.com
} 
To meet the ever increasing demand for biodiesel applications, it is necessary to develop high-yielding, and biotic and abiotic stress resistant $J$. curcas. However, conventional breeding is hampered by low and inconstant seed yield due to heterozygous nature of $J$. curcas plants and sexual incompatibilities due to deleterious gene linkages, followed by difficulty in obtaining large seed yield, fertile progenies and requires a very long time of cultivation [6]. Biotechnological innovations are envisaged for genetic upgrading of this crop wherein transgenic production will be the most important in achieving the above parameters. Agrobacterium-mediated genetic transformation is the most popular method of transferring genes of desirable traits into crop plants [4]. The natural ability of Agrobacterium for gene transfer to plants has been exploited for the genetic engineering of a range of plant species [24]. In order to breed advanced $J$. curcas varieties for large scale cultivation and produce more seeds, Agrobacterium-mediated genetic transformation of the species might be a possible solution.

To date, shoot regeneration of $J$. curcas had been successfully obtained in vitro [3] and transformed $J$. curcas plants have been recovered by the use of Agrobacterium tumefaciens mediating method [11, 12]. However, in all these reports, the periods for obtaining transformed plants as well as regenerated plants only were very long (90170 days). Recently, we have established a high efficient protocol for J. curcas genetic transformation, which used petiole explants and by incorporating methods of pretreatment of the explants with high concentration TDZ solution and grafting the regenerated shoot-buds to seedling stocks. Details of the experiments are described below.

\section{MATERIALS AND METHODS}

\section{Preparation of petioles explants}

Seeds of J. curcas coded M-19 [15] were surface-sterilized for $60 \mathrm{~s}$ with $75 \%(\mathrm{v} / \mathrm{v})$ ethanol after removing the outer seed coat, immersed in $2 \%(\mathrm{v} / \mathrm{v})$ sodium hypochlorite $(\mathrm{NaClO})$ for $20 \mathrm{~min}$ and finally rinsed 5 times in sterile distilled water. The embryos were removed from the seed and incubated on hormone-free Murashige and Skoog salt (MS) medium [22]. In vitro petioles were excised from 30-day-old seedlings, cut into small pieces $(0.5 \mathrm{~cm}$ in length), and used as explants.

\section{Treating the petiole explants with TDZ solution}

TDZ (Sigma-Aldrich Co., St. Louis, MO, USA) was dissolved in $1 \mathrm{~mol} / \mathrm{L} \mathrm{NaOH}$ solution. The solution was diluted with purified water to make the following concentrations: $0,5,10,20,30,60$ and $120 \mathrm{mg} / \mathrm{L}$. Before use, these stocked solutions were adjusted with $1 \mathrm{~mol} / \mathrm{L} \mathrm{HCl}$ to obtain a $\mathrm{pH}$ value range of 5.8-6.0, and filter-sterilized. Petiole explants were soaked in glass bottles containing different concentrations 
$(0,5,10,20,30,60$ and $120 \mathrm{mg} / \mathrm{L})$ of TDZ solution for various time durations $(0,5$, $10,20,40,60$ and $80 \mathrm{~min}$ ). After treatment, the explants were briefly placed on sterile dry filter paper in Petri dish for removing the surface water.

\section{Direct induction of adventitious shoot-bud regeneration and their elongation}

For inducing shoot-buds regeneration, petiole explants were inoculated on hormonefree MS medium after treated with TDZ solution for various time durations. For comparison, petiole explants were also treated by using conventional methods and inoculated on MS medium containing different concentrations of TDZ $(0,0.2,0.4,0.8$ and $1.6 \mathrm{mg} / \mathrm{L}$ ) as in previous reports [12]. The percentage of induction of shoot buds and the number of shoot buds per explant were recorded after 30 days of culture.

For elongation growth of the shoot-buds, the regenerated buds were transferred along with the mother tissues (explants) to MS medium supplemented with $0.5 \mathrm{mg} / \mathrm{L}$ BA, $0.2 \mathrm{mg} / \mathrm{L} \mathrm{KT}, 0.25 \mathrm{mg} / \mathrm{L}$ IAA, and $0.4 \mathrm{mg} / \mathrm{L}$ of $\mathrm{GA}_{3}$ (Sigma-Aldrich Co., St. Louis, MO, USA) [3, 14]. The length of the elongated shoots was recorded after 15 days of culture.

\section{In vitro grafting and culture of the grafted plantlets}

Shoots with length $\geq 0.5 \mathrm{~cm}$ were isolated from 15-day-old germinated surface-sterilized embryos of seeds of $J$. curcas as scions and hypocotyls with $0.2 \mathrm{~cm}$ radical were obtained from 5-day-old germinated surface-sterilized embryos of seeds of $J$. curcas as stocks. The upper surface of the hypocotyls stocks was cut longitudinally at the middle to about $5 \mathrm{~mm}$ depth, and then one scion was cut to have a "V" shape base and inserted into the cutting at the middle $[3,16]$. After in vitro grafting the grafted plantlets were planted to $1 / 2$ strength MS medium supplemented with 0.1 $\mathrm{mg} / \mathrm{L}$ IBA and different concentrations $(0,0.5,1,2,4$ and $8 \mathrm{mg} / \mathrm{L})$ of sodium nitroprusside (SNP).

\section{Agrobacterium strains and binary vectors}

The DNA fragment containing the cauliflower mosaic virus-35S (CaMV35S) promoter and the GUS gene from the vector pBI121 [8] were inserted into the Sal I and $B a m \mathrm{H}$ I sites of the vector of pCAMBIA 1300 to result in $\mathrm{p} 1300 \mathrm{G}$. The binary vector p1300G carried the selectable marker gene for hygromycin phosphotransferase (hpt) [27]. It was transformed into Agrobacterium tumefaciens strain EHA105 using the liquid nitrogen freeze-thaw method [5]. A single colony of the transformed bacteria was used to inoculate liquid YEB medium [10] supplemented with kanamycin (100 
$\mathrm{mg} / \mathrm{L})$ and chloramphenicol $(34 \mathrm{mg} / \mathrm{L})$. Bacterial cultures were grown overnight at $28^{\circ}$. Agrobacterium cells were collected by centrifugation at $12,000 \mathrm{rpm}$ for $10 \mathrm{~min}$ at $25^{\circ}$. The precipitate was resuspended with $20 \mathrm{~mL}$ of liquid MS medium containing $100 \mathrm{mg} / \mathrm{L}$ acetosyringone (AS) and $2 \mathrm{~g} / \mathrm{L}$ inositol, and adjusted to an $\mathrm{OD}_{600}$ of $0.1-$ 0.2 , prior to transformation.

\section{Transformation of $\mathrm{J}$. curcas petiole explants}

In vitro petiole explants were prepared by isolating the petioles from 20-day-old seedlings. After treated with $20 \mathrm{mg} / \mathrm{L} \mathrm{TDZ}$ solution for $20 \mathrm{~min}$ and soaked in the Agrobacterium cells harboring p1300G in $20 \mathrm{~mL}$ of MS liquid medium supplemented with $100 \mathrm{mg} / \mathrm{L} \mathrm{AS}$ and $2 \mathrm{~g} / \mathrm{L}$ inositol for $30 \mathrm{~s}$, the explants were inoculated on preculture medium (hormone-free MS medium) for 1 day, on co-cultivation medium (MS medium supplemented with $100 \mathrm{mg} / \mathrm{L} \mathrm{AS}, 2 \mathrm{~g} / \mathrm{L}$ inositol and $7 \mathrm{~g} / \mathrm{L}$ agar) for 2 days, and then on regeneration and selection medium (MS medium containing $3 \mathrm{mg} / \mathrm{L}$ hygromycin, $200 \mathrm{mg} / \mathrm{L}$ cefotaxime and $200 \mathrm{mg} / \mathrm{L}$ carbenicillin) for 30 days to induce adventitious buds [19]. Finally, the regenerated shoot-buds were transferred to MS medium containing $0.5 \mathrm{mg} / \mathrm{L} \mathrm{BA}, 0.2 \mathrm{mg} / \mathrm{L} \mathrm{KT}, 0.25 \mathrm{mg} / \mathrm{L} \mathrm{IAA}, 0.4 \mathrm{mg} / \mathrm{L} \mathrm{GA}_{3}, 200$ $\mathrm{mg} / \mathrm{L}$ cefotaxime, and $200 \mathrm{mg} / \mathrm{L}$ carbenicillin for 15 days for elongation growth.

\section{PCR assay and growth of the transgenic plantlets}

Genomic DNA of putative transformants shoots and control plants were extracted from young leaves about $2 \mathrm{~mm}$ in diameter with the help of the kit of Mighty Amp DNA polymerase Ver.2 (Takara). To verify the presence of the introduced $h t p$ gene in elongated shoots, PCR amplification of $871 \mathrm{bp}$ of the $h t p$ coding region was carried out with the primers F1 (5'-GCGAGTACTTCTACACAGCC-3') and F2 (5'-GCTTTCAGCTTCGATGTAGG-3'). The reaction mixture for PCR was incubated in a DNA thermal cycler under the following conditions: $98^{\circ}$ for $2 \mathrm{~min}$, followed by 30 cycles of $98^{\circ}$ for $10 \mathrm{~s}, 60^{\circ}$ for $15 \mathrm{~s}$, and $68^{\circ}$ for $50 \mathrm{~s}$, followed by a final 10 min extension at $68^{\circ}$. PCR products were separated on a $1.2 \%$ agarose gel run at 100 Volt for 25 min and photographed by using gel documentation system (BIORAD, USA).

The PCR positive shoots were isolated from the mother tissues as scions and hypocotyls with $0.2 \mathrm{~cm}$ radical were obtained from 5 days old germinated surfacesterilized embryos of seeds of $J$. curcas as stocks. After in vitro grafting the grafted plantlets were inoculated in half-strength MS medium containing $0.1 \mathrm{mg} / \mathrm{L} \mathrm{IBA}$ and $2 \mathrm{mg} / \mathrm{L}$ SNP for further growth. 


\section{Acclimatization and transplantation of transformed plantlets}

Transgenic plantlets were taken from culture bottles, washed thoroughly for removing residual medium, transplanted to pots with sterilized sand and soil in the ratio 1:1 and covered with transparent plastic sheet for 10 days. The established plants were then transferred to a greenhouse (temperature $25 \pm 1^{\circ}$ and relative humidity $70-80 \%$ ) for further growth.

\section{GUS histochemical assay}

Leaves of putatively transformed shoots recovered on hygromycin-selection media were used in the assays. The specific steps of GUS histochemical assay refer to the method reported by Jefferson [7].

\section{Southern hybridization}

Genomic DNA $(20 \mu \mathrm{g})$ from transformants was digested with EcoR I, separated by electrophoresis in a $0.8 \%$ agarose gel and transferred onto a Hybond $\mathrm{N}^{+}$membrane (Amersham Pharmacia, UK) by capillary method using alkaline transfer buffer $(0.4$ $\mathrm{M} \mathrm{NaOH}$ with $1 \mathrm{M} \mathrm{NaCl}$ ). The specific steps of Southern hybridization refer to the method reported by Deore and Johnson [3].

\section{RESULTS}

\section{Regeneration and elongation of adventitious buds from petiole explants with conventional culture methods}

The concentration of TDZ in the medium influenced the response of the petiole explants evidently with $0.4 \mathrm{mg} / \mathrm{L}$ TDZ induced the highest percentage $(47.36 \%)$ and the largest number (5.42) of shoot-buds per explant (Table 1, Fig. 1A) among the concentrations of TDZ tested. Moreover, the best elongation effects $(1.06 \mathrm{~cm}$ mean length) of shoot-buds and the largest number of shoot-buds with more than 2 leaves per explant (1.18) were realized also in the treatment with $0.4 \mathrm{mg} / \mathrm{L} \mathrm{TDZ}$ (Table 1 and Fig. 1C).

\section{Regeneration and elongation of adventitious buds from petiole explants pretreated with TDZ solution}

Petiole explants were treated with $20 \mathrm{mg} / \mathrm{L}$ TDZ for various time durations before inoculation of the explants to hormone-free MS medium. From the data shown in 
Table 1

Regeneration and elongation of adventitious buds from petiole explants of $J$. curcas with conventional culture methods*

\begin{tabular}{|c|c|c|c|c|}
\hline TDZ $(\mathrm{mg} / \mathrm{L})$ & $\%$ Regeneration & No. buds per explant & $\begin{array}{c}\text { Mean shoot length } \\
(\mathrm{cm})\end{array}$ & $\begin{array}{c}\text { No. shoot-buds with } \\
\text { more than 2 leaves per explant }\end{array}$ \\
\hline 0 & $0 \mathrm{~d}^{* *}$ & $0 \mathrm{~d}$ & $0 \mathrm{c}$ & $0 \mathrm{c}$ \\
\hline 0.2 & $38.23 \pm 2.36 \mathrm{~b}$ & $3.89 \pm 0.61 \mathrm{~b}$ & $0.69 \pm 0.11 \mathrm{~b}$ & $0.86 \pm 0.17 \mathrm{ab}$ \\
\hline 0.4 & $47.36 \pm 2.21 \mathrm{a}$ & $5.42 \pm 0.48 \mathrm{a}$ & $1.06 \pm 0.08 \mathrm{a}$ & $1.18 \pm 0.12 \mathrm{a}$ \\
\hline 0.8 & $36.42 \pm 3.32 \mathrm{~b}$ & $3.67 \pm 0.35 \mathrm{~b}$ & $0.87 \pm 0.13 \mathrm{ab}$ & $1.02 \pm 0.15 \mathrm{a}$ \\
\hline 1.6 & $23.28 \pm 2.47 \mathrm{c}$ & $2.82 \pm 0.31 \mathrm{c}$ & $0.53 \pm 0.15 \mathrm{~b}$ & $0.74 \pm 0.11 \mathrm{~b}$ \\
\hline
\end{tabular}

*Data for elongation were obtained by inoculating the regenerated shoot-buds with mother tissues to fresh MS medium containing $0.5 \mathrm{mg} / \mathrm{L} \mathrm{BA}, 0.2 \mathrm{mg} / \mathrm{L} \mathrm{KT}, 0.25 \mathrm{mg} / \mathrm{L} \mathrm{IAA}$ and $0.4 \mathrm{mg} / \mathrm{L}$ of GA .

$* *$ Values represent means \pm SD (standard deviation) of 25-30 explants per treatment in three independent experiments. Data in the same column followed by different letters are significantly different at $p \leq 5 \%$ level as determined by Duncan's multiple range test.

Table 2

Effect of treating explants with $20 \mathrm{mg} / \mathrm{L} \mathrm{TDZ}$ solution for various time durations on the regeneration of adventitious buds from petiole explants of $J$. curcas

\begin{tabular}{|c|c|c|}
\hline Treating duration (min) & Regeneration percentage (\%) & Number of buds per explant \\
\hline 0 & $0 \mathrm{~d}^{*}$ & $0 \mathrm{e}$ \\
\hline 5 & $45.78 \pm 2.44 \mathrm{c}$ & $5.28 \pm 0.50 \mathrm{~d}$ \\
\hline 10 & $62.58 \pm 3.19 \mathrm{~b}$ & $8.56 \pm 0.34 \mathrm{bc}$ \\
\hline 20 & $87.35 \pm 3.14 \mathrm{a}$ & $10.48 \pm 0.42 \mathrm{a}$ \\
\hline 40 & $66.39 \pm 4.53 \mathrm{~b}$ & $9.29 \pm 0.46 \mathrm{~b}$ \\
60 & $58.42 \pm 2.64 \mathrm{~b}$ & $7.25 \pm 0.41 \mathrm{c}$ \\
\hline 80 & $47.32 \pm 2.37 \mathrm{c}$ & $5.36 \pm 0.28 \mathrm{~d}$ \\
\hline
\end{tabular}

*Data in the same column followed by different letters are significantly different at $p \leq 5 \%$ level as determined by Duncan's multiple range test.

Table 2 it is clear that time duration of the treatment significantly influenced the response for shoot-buds induction, and treatment for 20 min was the most suitable in which the highest regeneration percentage $(87.35 \%)$ and the largest number of regenerated buds per explant were achieved (10.48).

\section{Regeneration and elongation of adventitious buds from petiole explants treated with various concentrations of TDZ solution before culture}

Treating the explants with $20 \mathrm{mg} / \mathrm{L}$ TDZ resulted in the highest percentage of shoot bud induction $(87.35 \%)$ and the largest number of shoot buds (10.48) per explant (Table 3, Fig. 1B). It is clear from the above results that treatment with this TDZ solution at a certain range of concentration for a relatively short time was much more 
effective than conventional methods for adventitious bud induction (Tables 1, 3). Moreover, the regenerated buds elongated better on hormone-free MS medium than those on medium containing cytokinin as by conventional methods (Tables 1,3). The best elongation and growth of the regenerated buds was observed in the treatment of treating the petiole explants with $20 \mathrm{mg} / \mathrm{L} \mathrm{TDZ}$ solution for $20 \mathrm{~min}$ and then inoculating the explants on hormone-free MS medium, where the greatest mean shoot length $(1.78 \mathrm{~cm})$ and the largest number of shoot-buds with more than 2 leaves per explant (3.15) were achieved (Table 3, Fig. 1D).
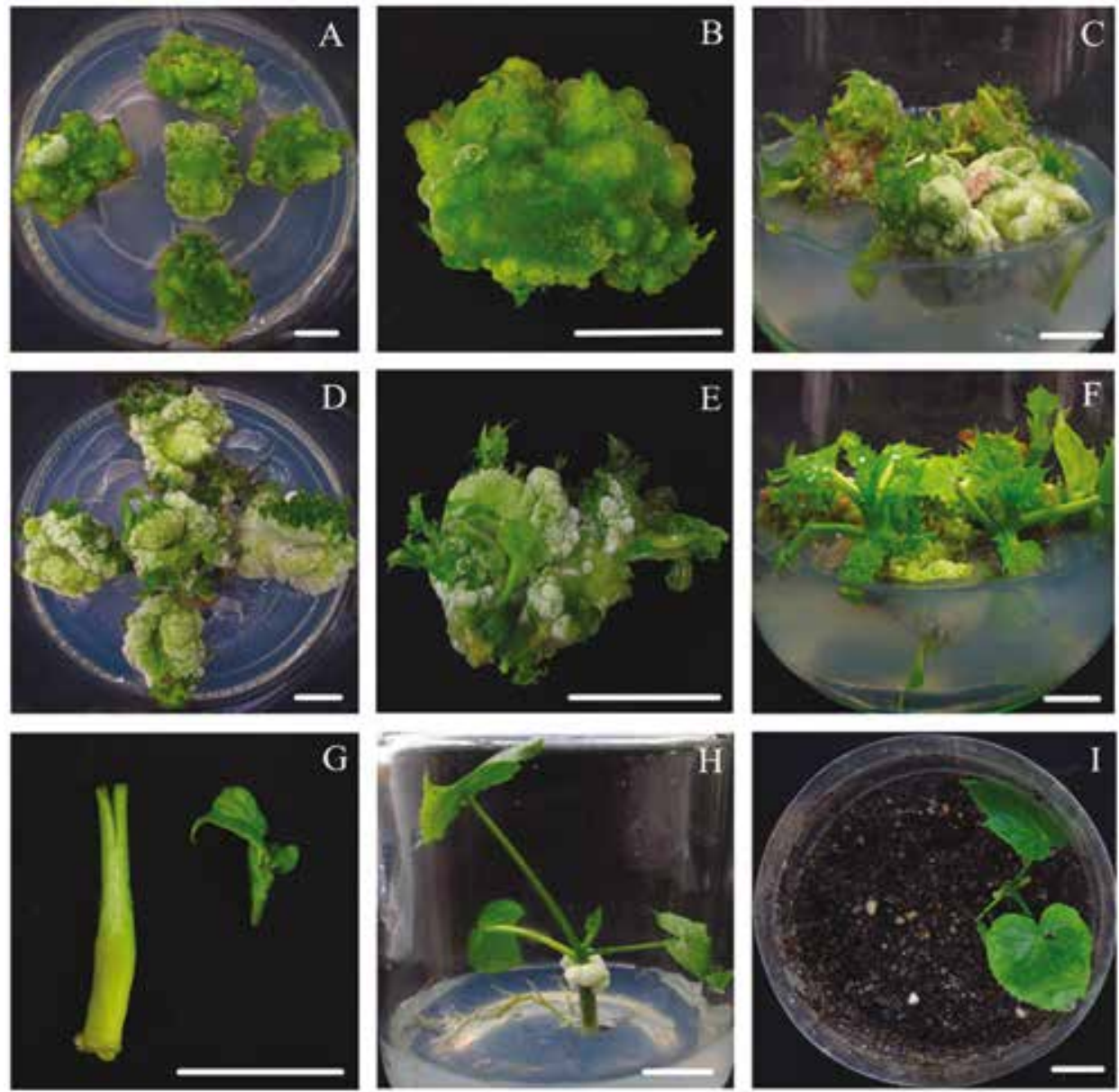

Fig. 1. Direct induction of shoot-buds and elongation of the regenerated buds from petiole explants of J. curcas. A and B (close up) - petiole explants were inoculated on MS medium containing $0.4 \mathrm{mg} / \mathrm{L} \mathrm{TDZ}$ for 30 days; C and D (close up) - petiole explants were treated with $20 \mathrm{mg} / \mathrm{L} \mathrm{TDZ}$ solution for $20 \mathrm{~min}$ and inoculated on hormone-free MS medium for 30 days; $\mathrm{E}$ - elongation of regenerated shoot-buds by conventional method and; F - by treatment with TDZ solution and culture for 15 days; G - a hypocotyl stock (left) with a $0.2 \mathrm{~cm}$ radical prepared from a 5-day-old seedling, and a shoot scion (right) isolated from a 15-day-old seedling; $\mathrm{H}$ - a grafted plantlet growing on half-strength MS medium for 20 days; I - a grafted plantlet in a plastic bottle 10 days after transplantation $($ bars $=1 \mathrm{~cm}$ ) 
Table 3

Effect of treating petiole explants with various concentrations of TDZ solution on the regeneration of adventitious buds in J. curcas*

\begin{tabular}{|c|c|c|c|c|}
\hline $\begin{array}{c}\text { TDZ } \\
(\mathrm{mg} / \mathrm{L}) * *\end{array}$ & \% Regeneration & No. buds per explant & $\begin{array}{c}\text { Mean shoot length } \\
(\mathrm{cm})\end{array}$ & $\begin{array}{c}\text { No. shoot-buds with more than 2 } \\
\text { leaves per explant }\end{array}$ \\
\hline 0 & $0 \mathrm{f}^{* * *}$ & $0 \mathrm{f}$ & $0 \mathrm{~d}$ & $0 \mathrm{~d}$ \\
\hline 5 & $40.21 \pm 2.93 \mathrm{~d}$ & $5.46 \pm 0.32 \mathrm{~d}$ & $1.39 \pm 0.12 \mathrm{bc}$ & $2.14 \pm 0.13 \mathrm{~b}$ \\
\hline 10 & $56.15 \pm 2.76 \mathrm{c}$ & $7.47 \pm 0.22 \mathrm{c}$ & $1.55 \pm 0.09 \mathrm{~b}$ & $2.87 \pm 0.16 \mathrm{a}$ \\
\hline 20 & $87.35 \pm 3.14 \mathrm{a}$ & $10.48 \pm 0.42 \mathrm{a}$ & $1.78 \pm 0.14 \mathrm{a}$ & $3.15 \pm 0.22 \mathrm{a}$ \\
\hline 30 & $70.46 \pm 3.27 \mathrm{~b}$ & $9.31 \pm 0.19 \mathrm{~b}$ & $1.63 \pm 0.11 \mathrm{ab}$ & $3.01 \pm 0.19 \mathrm{a}$ \\
\hline 60 & $55.29 \pm 2.68 \mathrm{c}$ & $7.38 \pm 0.31 \mathrm{c}$ & $1.41 \pm 0.13 \mathrm{bc}$ & $2.23 \pm 0.14 \mathrm{~b}$ \\
\hline 120 & $24.47 \pm 2.29 \mathrm{e}$ & $3.64 \pm 0.41 \mathrm{e}$ & $1.18 \pm 0.12 \mathrm{c}$ & $1.71 \pm 0.15 \mathrm{c}$ \\
\hline
\end{tabular}

*Data for elongation were obtained by inoculating the regenerated shoot-buds with mother tissues to fresh MS medium containing $0.5 \mathrm{mg} / \mathrm{L} \mathrm{BA}, 0.2 \mathrm{mg} / \mathrm{L} \mathrm{KT}, 0.25 \mathrm{mg} / \mathrm{L} \mathrm{IAA}$ and $0.4 \mathrm{mg} / \mathrm{L}$ of $\mathrm{GA}_{3}$.

**All explants were treated with TDZ solution for $40 \mathrm{~min}$.

***Values represent means $\pm \mathrm{SD}$ (standard deviation) of 25-30 explants per treatment in three independent experiments. Data in the same column followed by different letters are significantly different at $p \leq 5 \%$ level as determined by Duncan's multiple range test.

\section{Influence of SNP on the growth of grafted plantlets}

It is clear (Table 4) that the influences of SNP on plant height, root number and the survival rate after transplantation were all significant. The best result was obtained when the grafted plantlets were inoculated on $1 / 2$ strength MS medium supplemented with $2 \mathrm{mg} / \mathrm{L} \mathrm{SNP}$, where the grafted plantlets were the highest $(1.86 \mathrm{~cm})$ with the largest number of roots (4.68) and the highest survival rate (78.45\%) after transplantation (Table 4).

Table 4

Influences of SNP on the growth of grafted plantlets of $J$. curcas

\begin{tabular}{|c|c|c|c|}
\hline SNP $(\mathrm{mg} / \mathrm{L})$ & Plant height $(\mathrm{cm})$ & No. roots & \% Survival after transplantation \\
\hline 0 & $0.91 \pm 0.06 \mathrm{~d}^{*}$ & $1.68 \pm 0.18 \mathrm{~d}$ & $53.69 \pm 3.17 \mathrm{~d}$ \\
\hline 0.5 & $1.43 \pm 0.07 \mathrm{c}$ & $2.45 \pm 0.28 \mathrm{c}$ & $68.20 \pm 3.17 \mathrm{c}$ \\
\hline 1 & $1.64 \pm 0.10 \mathrm{~b}$ & $3.67 \pm 0.32 \mathrm{~b}$ & $71.23 \pm 3.25 \mathrm{~b}$ \\
\hline 2 & $1.86 \pm 0.08 \mathrm{a}$ & $4.68 \pm 0.27 \mathrm{a}$ & $78.45 \pm 2.54 \mathrm{a}$ \\
\hline 4 & $1.55 \pm 0.09 \mathrm{bc}$ & $3.08 \pm 0.34 \mathrm{~b}$ & $65.46 \pm 2.31 \mathrm{c}$ \\
\hline 8 & $0.87 \pm 0.05 \mathrm{~d}$ & $2.01 \pm 0.22 \mathrm{~cd}$ & $49.28 \pm 2.06 \mathrm{~d}$ \\
\hline
\end{tabular}

*Data in the same column followed by different letters are significantly different at $p \leq 5 \%$ level as determined by Duncan's multiple range test. 


\section{Production of transgenic plants of $\mathrm{J}$. curcas}

Establishment of an Agrobacteriuim-mediated transformation method using petiole explants was attempted on the bases of the above experiments. Petiole explants were treated with $20 \mathrm{mg} / \mathrm{L} \mathrm{TDZ} \mathrm{solution} \mathrm{for} 20 \mathrm{~min}$, inoculated on preculture medium (hormone-free MS medium) for one day (Fig. 3A), and incubated with Agrobacterium strain EHA105 harboring pCAMBIA1300G (Fig. 2) for 30 s. After 2 days of cocultivation in the dark (Fig. 3B), the explants were then transferred onto regeneration and selection medium (MS medium with $3 \mathrm{mg} / \mathrm{L}$ hygromycin, $200 \mathrm{mg} / \mathrm{L}$ cefotaxime and $200 \mathrm{mg} / \mathrm{L}$ carbenicillin) (Fig. 3C) for 30 days. Petiole explants with regenerated resistant buds were transferred into and cultured on the elongation medium for 15 days to obtain elongated resistant shoots (Fig. 3D). Genomic DNA of elongation shoots were extracted from young leaves about $2 \mathrm{~mm}$ in width, and PCR with primers specific for $h p t$ gene was performed with the help of the kit of MightyAmp DNA polymerase Ver.2 (Takara). A DNA band of about 871 bp was detected in the transgenic lines, while this band was not detected in non-transformed control plants (Fig. 3E). A total of 83 transgenic shoots confirmed by PCR were obtained from four independent experiments which consisted of 323 petiole explants (Table 5).

In the present study, grafting was employed to obtain transformed plantlets. The PCR assayed positive shoots were isolated from the mother tissues as scions, and stocks of hypocotyls with $2 \mathrm{~mm}$ radical were prepared from 5-day-old sterile seedlings of $J$. curcas. After in vitro grafting, the grafted plantlets were inoculated to $1 / 2$

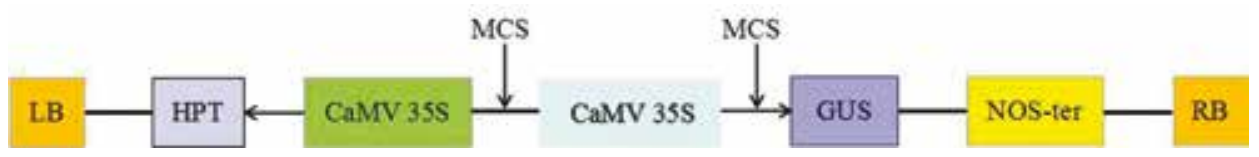

Fig. 2. Structure diagram of pCAMBIA 1300G-GUS vector. LB - The left border of T-DNA; HPT Hygromycin phosphotransferase gene; CaMV35S - Cauliflower mosaic virus (CaMV) 35S promoter; MCS - multiple cloning site; GUS - Beta-glucuronidase gene; NOS-ter - The terminator of nopaline synthase gene; RB - The right of T-DNA

Table 5

Summary of Agrobacteriuim-mediated petiole receptors transformation results in J. curcas*

\begin{tabular}{|c|c|c|c|c|c|}
\hline $\begin{array}{c}\text { Serial No. } \\
\text { experiment }\end{array}$ & No. explants & $\begin{array}{c}\text { No. explants } \\
\text { forming resistant } \\
\text { shoots }\end{array}$ & No. resistant buds & $\begin{array}{c}\text { No. elongated } \\
\text { resistant shoots with } \\
\text { length } \geq 0.5 \mathrm{~cm}\end{array}$ & $\begin{array}{c}\text { No. positive shoots } \\
\text { by PCR (\%) }\end{array}$ \\
\hline 1 & 78 & 19 & 24 & 23 & $22(98.65)$ \\
\hline 2 & 92 & 23 & 27 & 24 & $24(100)$ \\
\hline 3 & 84 & 21 & 26 & 22 & $20(90.91)$ \\
\hline 4 & 69 & 16 & 20 & 18 & $17(97.44)$ \\
\hline Total & 323 & 79 & 97 & 87 & $83(95.40)$ \\
\hline
\end{tabular}

*Elongated resistant shoots with length $\geq 0.5 \mathrm{~cm}$ were checked by PCR. 
strength MS medium containing $0.1 \mathrm{mg} / \mathrm{L}$ IBA and $2 \mathrm{mg} / \mathrm{L}$ SNP where the grafted plantlets grew vigorously and were ready for transplantation to the soil in 20 days (Fig. 3F).
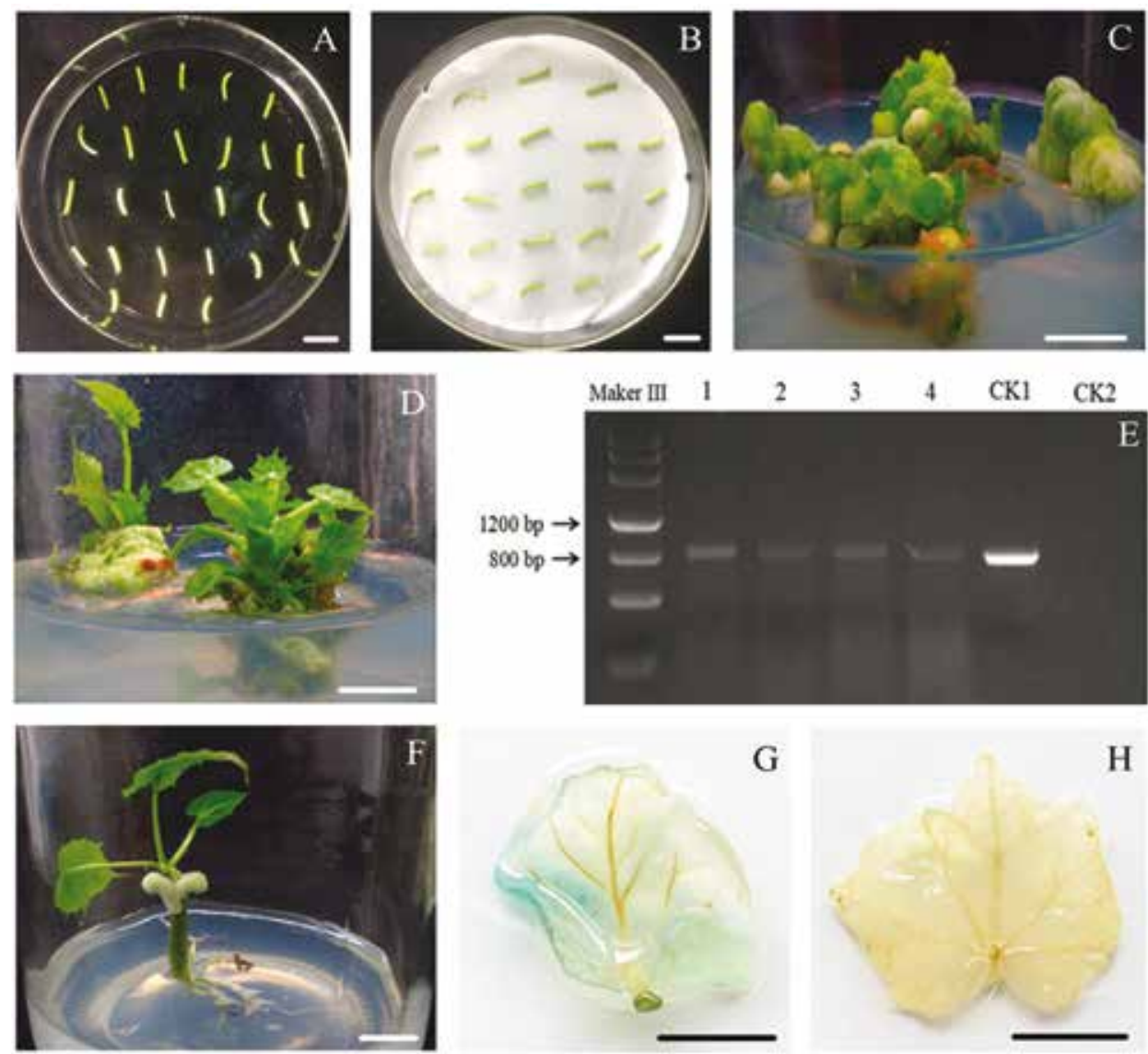

G

Fig. 3. Transformation of J. curcas. A - petiole explants inoculated on preculture medium; B Agrobacterium infected petiole explants on a piece of filter paper on co-cultivation medium for two days; $\mathrm{C}$ - petiole explants on MS medium containing $3 \mathrm{mg} / \mathrm{L}$ hygromycin, $200 \mathrm{mg} / \mathrm{L}$ cefotaxime and $200 \mathrm{mg} / \mathrm{L}$ carbenicillin for 30 days; D - hygromycin-resistant buds along with the mother tissue on MS medium supplemented with $0.5 \mathrm{mg} / \mathrm{L} \mathrm{BA}, 0.2 \mathrm{mg} / \mathrm{L}$ kinetin, $0.25 \mathrm{mg} / \mathrm{L}$ indole-3-acetic acid, $0.4 \mathrm{mg} / \mathrm{L}$ gibberellic acid, $200 \mathrm{mg} / \mathrm{L}$ cefotaxime and $200 \mathrm{mg} / \mathrm{L}$ carbenicillin for 15 days; E - PCR amplification of hpt gene in some transgenic lines (lanes 1 to 4 ), the plasmid control (CK1, p1300G) and the untransformed control (CK2); F - a grafted plantlet was inoculated on 1/2 strength MS medium supplemented with $0.1 \mathrm{mg} / \mathrm{L}$ IBA and $2 \mathrm{mg} / \mathrm{L}$ L-glutamine for 20 days; $\mathrm{G}$ - a grafted plant survived the transplantation; $\mathrm{H}$ - GUS assay of a leaf of transformed plant and I - a leaf of non-transformed plant (bars $=1 \mathrm{~cm}$ ) 

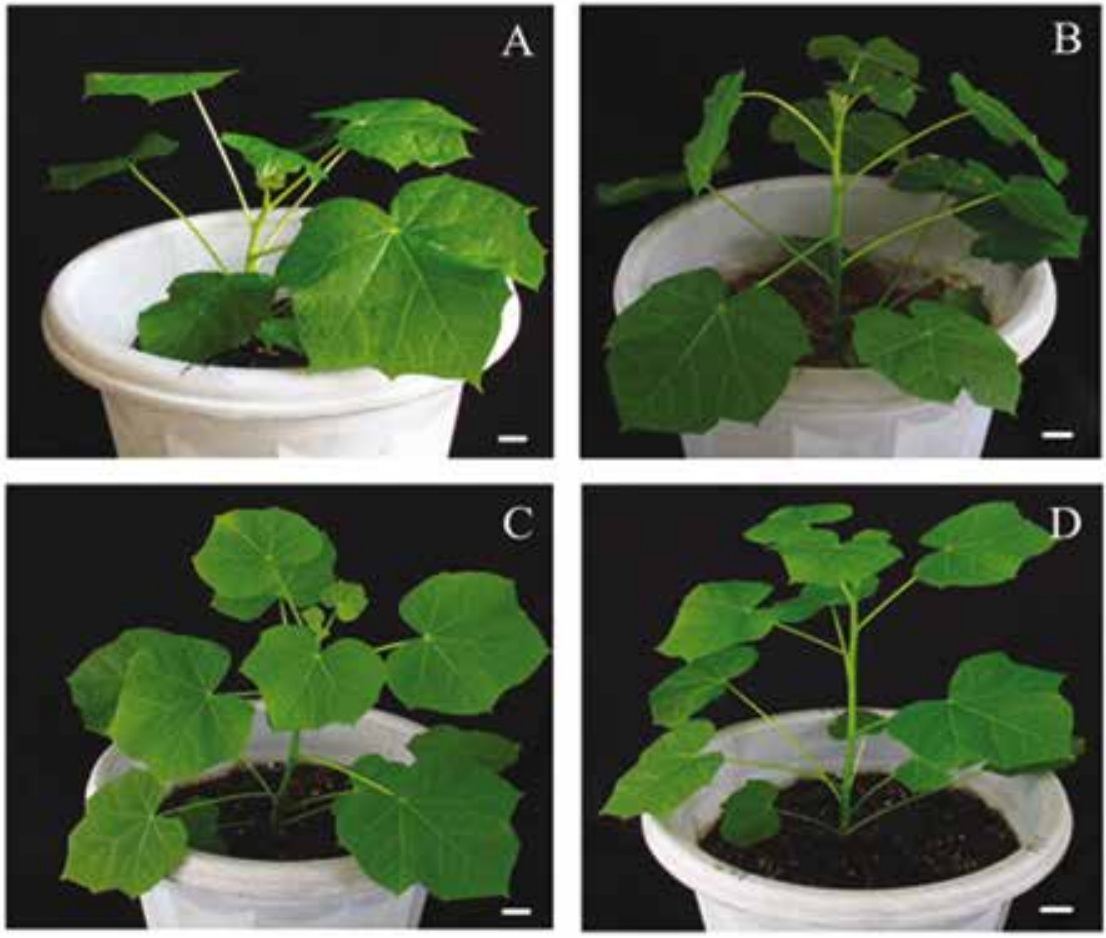

WT

1

2

3

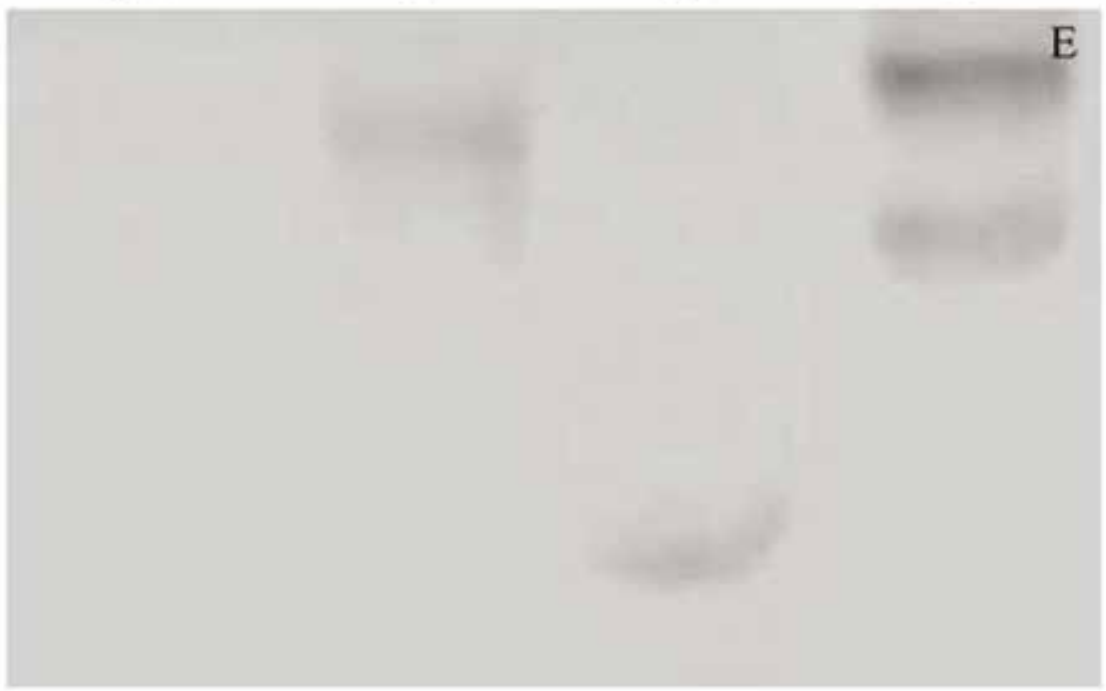

Fig. 4. Southern hybridization using hpt gene as a probe in transgenic lines. A - a non-transformed plant; $\mathrm{B}, \mathrm{C}$ and D - three transgenic lines; E - results of southern hybridization; WT - a non-transformed plant; lanes 1,2 and 3 - the three transgenic lines 


\section{GUS histochemical analysis}

The leaves from the putatively transformed shoots of grafted plantlets and WT plants were assayed histochemically for gus gene expression. An intense blue colour was observed from the putatively transformed leaves (Fig. 3G), whereas no such blue colour was observed from the WT leaf samples (Fig. 3H), indicating that gus gene was integrated and expressed in the transformed $J$. curcas genome.

\section{Southern blot analysis}

For certificating the stable transformation of $J$. curcas plants with the hpt gene, a control plant (Fig. 4A) and three putative transgenic lines (Fig. 4B-D) were subjected to DNA gel blot hybridization (Fig. 4E). No hybridization band was detected for control plant DNA as the hpt probe did not hybridize to genomic DNA from any of the tested plants regenerated from petiole explants without Agrobacterium infection (lane WT). In EcoR I digestion of genomic DNA from each of the three putative transgenic lines, two lines showed single copy integration (lanes 1 and 2) and the rest showed double copy integration (lane 3), indicating that all the three lines had integrated $h p t$ gene into the genome.

\section{DISCUSSION}

TDZ belongs to the cytokinin family. In plant tissue culture, cytokinin is an essential factor for the induction of adventitious buds formation in most cases [12]. Our present study indicated that cytokinin was required for only a short period for inducing shootbuds formation, and this was consistent with our previous study where high concentrations of BA were used to treat soybean hypocotyl explants for short duration and obtain higher regeneration rates [18].

Grafting is a well known practice in horticulture, most commonly for propagation of elite genotypes by grafting buds or shoots of the elite variety to stocks of common varieties of the same species or of closely related species [17]. Very recently, this strategy has been applied in $J$. curcas genetic transformation practice for increasing the survival rate of putative transformed plants [22] or promoting the propagation of shoots [6]. However, in these two cases conventional grafting method was used rather than in vitro grafting method, and higher quality scions $(2.5-5 \mathrm{~cm}$ in length) were adopted $[6,11]$. In the in vitro grafting method described here, shoots a little longer than $0.5 \mathrm{~cm}$ could serve as scions and the grafted plantlets could be inoculated in antibiotics-free medium, so, much more regenerated shoots could meet the requirement as scions and the grafted plantlets could grow much better.

SNP is usually used as NO donor in plant tissue culture studies [25]. NO might interact with auxins for the regulation of plant cell division, dedifferentiation and 
redifferentiation [23]. Results in this study confirmed the effectiveness of SNP in the promotion of adventitious bud regeneration, but at the same time demonstrate that the effectiveness was sensitively dosage dependent.

A high efficient protocol has been established for J. curcas genetic transformation, which consists of infection of petiole explants with Agrobacterium, regeneration of adventitious bud from the explants and graft of the transformed shoots to seedling stocks (Fig. 5). By this protocol, elongated transformed shoots could be obtained within 50 days. Moreover, because only a small piece of leave ( $2 \mathrm{~mm}$ in diameter) from the elongated shoots could be used for molecular detection by the optimized PCR reaction system refined in the present study, the most common method of cetyltrimethyl ammonium bromide (CTAB) [20] which need longer time to obtain enough leaves or other tissues for DNA extraction [26], could be avoided. In addition, because the PCR positive shoots, even of those small and short ones $(<2.5 \mathrm{~cm}$ in longth), could be directly separated from their mother tissues and served as scions without an elongation culture step, transformed plantlets ready for transplantation could be obtained in shorter time than those reported previously [21]. This protocol

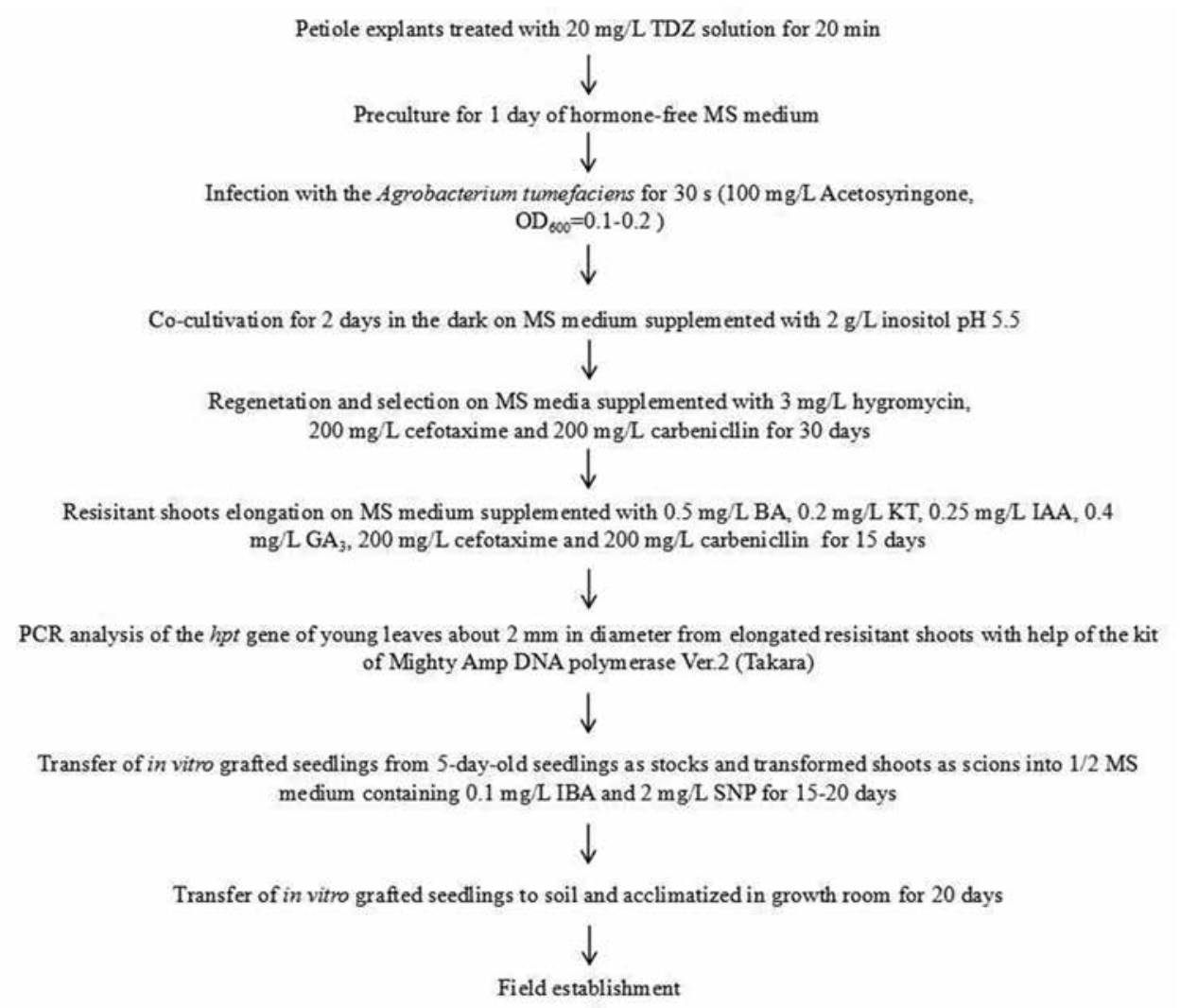

Fig. 5. A schematic summary of the complete protocol for Agrobacterium-mediated transformation in associating with shoot-bud regeneration of $J$. curcas using petiole explant as acceptor 
might largely facilitate the genetic modification and subsequent in vitro multiplication of $J$. curcas cultivars for various uses with the final aim of reducing the world's dependence on fossil reserves.

\section{ACKNOWLEDGEMENTS}

This work was supported by the Program for Scientific Research Start-up Funds of Guangdong Ocean University (R17023), the Project of Science and Technology of Zhangjiang City (2016B01004), the Project for Innovation and Strong School of Department of Education of Guangdong Province (2016KQNCX067), and the National College Students Innovation and Entrepreneurship Training Program (201610566019 and CXXL2017045).

\section{REFERENCES}

1. Adebowale, K. O., Adedire, C. O. (2006) Chemical composition and insecticidal properties of the underutilized Jatropha curcas seed oil. Afr. J. Biotechnol. 5, 901-906.

2. Attaya, A. S., Geelen, D., Belal, A. E. H. (2012) Progress in Jatropha curcas tissue culture. Am-Eurasian J. Sustain. Agric. 6, 6-13.

3. Deore, A. C., Johnson, T. S. (2008) High-frequency plant regeneration from leaf-disc cultures of Jatropha curcas L.: an important biodiesel plant. Plant Biotech Rep. 2, 10-15.

4. Hamilton, C. M., Frary, A., Lewis, C. (1996) Stable transfer of intact high molecular weight DNA into plant chromosomes. Proc. Natl. Acad. Sci. 93, 9975-9979.

5. Höfgen, R., Willmitzer, L. (1988) Storage of competent cells for Agrobacterium transformation. Nucleic Acids Res. 16, 9877.

6. Jaganath, B., Subramanyam, K., Mayavan, S. (2014) An efficient in planta transformation of Jatropha curcas (L.) and multiplication of transformed plants through in vivo grafting. Protoplasma 251, 591-601.

7. Jefferson, R. A. (1987) Assaying chimeric genes in plants: the GUS gene fusion system. Plant Mol. Biol. Rep. 5, 387-405.

8. Jefferson, R. A., Kavanagh, T. A., Bevan, M. W. (1987) GUS fusions: beta-glucuronidase as a sensitive and versatile gene fusion marker in higher plants. E. M. B. O. J. 6, 3901-3907.

9. Liberalino, A. A. A., Bambirra, E. A., Moraes-Santos, T. (1988) Jatropha curcas L. seeds: chemical analysis and toxicity. Arq. Biol. Technol. 31, 539-550.

10. Khemkladngoen, N., Cartagena, J. A., Fukui, K. (2011) Physical wounding-assisted Agrobacteriummediated transformation of juvenile cotyledons of a biodiesel-producing plant, Jatropha curcas L. Plant Biotechnol. Rep. 5, 235-243.

11. Kumar, N., Anand, K. G. V., Reddy, M. P. (2011) In vitro regeneration from petiole explants of nontoxic Jatropha curcas. Ind. Crops Prod. 33, 146-151.

12. Kumar, N., Reddy, M. P. (2012) Thidiazuron (TDZ) induced plant regeneration from cotyledonary petiole explants of elite genotypes of Jatropha curcas: a candidate biodiesel plant. Ind. Crops Prod. $39,62-68$.

13. Liberalino, A. A. A., Bambirra, E. A., Moraes-Santos, T. (1988) Jatropha curcas L. seeds: chemical analysis and toxicity. Arquivos de biologia e tecnologia 31, 539-550.

14. Liu, Y., Lu, J., Zhu, H. (2016) Efficient culture protocol for plant regeneration from cotyledonary petiole explants of Jatropha curcas L. Biotechnol. Biotec. Eq. 30, 907-914.

15. Liu, Y., Tong, X., Hui, W. (2015) Efficient culture protocol for plant regeneration from petiole explants of physiologically mature trees of Jatropha curcas L. Biotechnol. Biotec. Eq. 29, 479-488.

16. Liu, Y., Yin, X. G., Zhu, H. B. (2016) An efficient protocol for inducing regeneration in physic Nut (Jatropha curcas L.). Bangladesh J. Botany 45, 87-93. 
17. Liu, Y., Yu, L., Fu, Y. L. (2012) Development of an in vitro grafting method for the enhancement of growth of isolated shoots and buds in soybean (Glycine max L.). Biomed. Eng. Biotechnol. 1, 10031006.

18. Liu, Y., Yu, L., Zhang, Q. (2013) High concentration short duration treatment of benzyladenine stimulates adventitious bud regeneration from hypocotyl explants in soybean. Adv. Mater. Res. 647, 331-337.

19. Liu, Z. L., Liu, Y., Yang, Y. S. (2016) An Agrobacterium - mediated genetic transformation method of Jatropha curcas. Patent filed China and PCT. Authorization No. ZL201410275476.6, 2016-05-25. (in Chinese).

20. Lodhi, M. A., Ye, G. N., Weeden, N. F. (1994) A simple and efficient method for DNA extraction from grapevine cultivars and Vitis species. Plant Mol. Bio. Rep. 12, 6-13.

21. Lu, W. (2003) Induction of callus from Jatropha curcas and rapid propagation. Chin. J. Appl. Environ. Biol. 9, 127-130.

22. Murashige, T., Skoog, F. (1962) A revised medium for rapid growth and bio assays with tobacco tissue cultures. Physiol. Plant. 15, 473-497.

23. Ötvös, K., Pasternak, T. P., Miskolczi, P. (2005) Nitric oxide is required for, and promotes auxinmediated activation of, cell division and embryogenic cell formation but does not influence cell cycle progression in alfalfa cell cultures. The Plant J. 43, 849-860.

24. Petri, C., Wang, H., Alburquerque, N. (2008) Agrobacterium-mediated transformation of apricot (Prunus armeniaca L.) leaf explants. Plant Cell Rep. 27, 1317-1324.

25. Petřivalský, M., Vaníčková, P., Ryzí, M. (2012) The effects of reactive nitrogen and oxygen species on the regeneration and growth of cucumber cells from isolated protoplasts. Plant Cell Tiss. Org. Cult. 108, 237-249.

26. Wei, Q., Lu, W. D., Liao, Y. (2004) Plant regeneration from epicotyl explant of Jatropha curcas. J. Plant Physiol. Mol. Biol. 30, 475-478.

27. Zhou, L., Ni, E., Yang, J. (2013) Rice OsGL1-6 is involved in leaf cuticular wax accumulation and drought resistance. PloS One 8, e65139. 